\title{
Determination of Mineral Contents of Sorghum (Sorghum sp.) and Corn (Zea mays L.) Varieties Grown for Roughage
}

\author{
Mehmet Arif Ozyazici (Corresponding author) \\ Siirt University, Faculty of Agriculture, Department of Field Crops, Siirt, Turkey \\ E-mail: arifozyazici@siirt.edu.tr \\ Semih Acikbas \\ Siirt University, Faculty of Agriculture, Department of Field Crops, Siirt, Turkey \\ E-mail: semihacikbas@siirt.edu.tr
}

\begin{abstract}
In this research, it was aimed to determine some mineral contents of sorghum (Sorghum bicolor L.), sudangrass (Sorghum sudanense Staph.), Sorghum x sudangrass hybrid (Sorghum bicolor x Sorghum sudanense Stapf) and corn (Zea mays L.) cultivars grown as the second crop. Field experiments of the study was conducted under the ecological conditions of Siirt province in the Southeastern region of Turkey between 2016 and 2017. The plant material of the study consisted of two sorghum varieties (Master BMR and Rox), one sudangrass variety (Gözde-80), three sorghum x sudangrass hybrid (Forage King, Sugar Graze-II and Greengo) and three corn varieties (OSSK-644, Samada-07 and DKC6101). In the study, field trials were established with three replications according to randomized complete blocks experiment design. Phosphorus $(\mathrm{P})$, potassium $(\mathrm{K})$, calcium $(\mathrm{Ca})$ and magnesium $(\mathrm{Mg})$ analyzes were performed on the cultivars. According to the averages of two years of research, it was determined that $\mathrm{P}$, $\mathrm{K}, \mathrm{Ca}, \mathrm{Mg}, \mathrm{Ca} / \mathrm{P}$ and $\mathrm{K} / \mathrm{Ca}+\mathrm{Mg}$ ratios of dry feed obtained from sorghum and corn varieties varied between $0.25-0.30 \%, 1.31-2.20 \%, 0.61-0.81 \%, 0.210-0.262 \%, 2.26-2.88$, and $1.25-2.54$ respectively. Sorghum and corn varieties were sufficient to meet the needs of animals in terms of forage K content; however, $\mathrm{P}, \mathrm{Ca}$ and $\mathrm{Mg}$ ratios were below the limit values that should be in feed rations.
\end{abstract}

Keywords: Phosphorus, Potassium, Calcium, Magnesium, Sorghum bicolor L., Zea mays L.

DOI: $10.7176 / J S T R / 5-12-24$

\section{Kaba Yem Amacıyla Yetiştirilen Sorgum (Sorghum sp.) ve Mısır (Zea mays L.) Çeşitlerinin Mineral İçeriklerinin Değişimi}

\begin{abstract}
Özet
$\mathrm{Bu}$ araștırmada, ikinci ürün olarak yetiștirilen sorgum (Sorghum bicolor L.), sudanotu (Sorghum sudanense Staph.), sorgum x sudanotu melezi (Sorghum bicolor x Sorghum sudanense Stapf) ve misır (Zea mays L.) çeşitlerinin bazı mineraller yönünden içeriklerinin belirlenmesi amaçlanmıştır. Araştırma tarla denemesi, Türkiye'nin Güneydoğu Anadolu Bölgesi'nde yer alan Siirt ili ekolojik koşullarında, 2016 ve 2017 yıllarında yürütülmüştür. Çalışmanın bitkisel materyalini; 2 adet sorgum çeşidi (Master BMR ve Rox), 1 adet sudanotu çeşidi (Gözde-80), 3 adet sorgum x sudanotu melezi çeşidi (Forage King, Sugar Graze-II ve Greengo) ve 3 adet misır çeşidi (OSSK-644, Samada-07 ve DKC6101) oluşturmuştur. Araştırmada tarla denemeleri, tesadüf blokları deneme desenine göre 3 tekrarlamalı olarak kurulmuştur. Ele alınan çeşitlerde fosfor $(\mathrm{P})$, potasyum $(\mathrm{K})$, kalsiyum $(\mathrm{Ca})$ ve magnezyum $(\mathrm{Mg})$ analizleri yapılmıştır. İki yıllık araştırma sonucu ortalamalarına göre, sorgum ve mısır çeşitlerinden elde edilen kaba yemlerin kuru maddesindeki $\mathrm{P}, \mathrm{K}, \mathrm{Ca}, \mathrm{Mg}, \mathrm{Ca} / \mathrm{P}$ ve $\mathrm{K} / \mathrm{Ca}+\mathrm{Mg}$ oranlarının sırasıyla \% 0.25-0.30, \% 1.31-2.20, \% 0.61-0.81, \% 0.210-0.262, 2.26-2.88 ve 1.25-2.54 arasında değişim gösterdiği belirlenmiştir. Sorgum ve mısır çeşitlerine ait kaba yemlerin $\mathrm{K}$ yönünden hayvanların ihtiyacını karşılamada yeterli düzeyde olduğu; P, Ca ve Mg oranlarının ise yem rasyonlarında olması gereken sınır değerin altında olduğu belirlenmiştir.
\end{abstract}

Anahtar Kelimeler: Fosfor, Potasyum, Kalsiyum, Magnezyum, Sorghum bicolor L., Zea mays L. 


\section{Giris}

Mineral maddeler içerisinde yer alan özellikle fosfor $(\mathrm{P})$, potasyum $(\mathrm{K})$, kalsiyum $(\mathrm{Ca})$ ve magnezyum $(\mathrm{Mg})$ gibi makro elementler hayvanların beslenmesinde diğer besin maddeleri kadar büyük önem taşımaktadır (Ergül, 1993; Gülümser ve ark., 2017). Bu mineraller hayvanların iskelet sistemi, dişlerin ve kemiklerin yapısında, kas ve sinir sisteminin gelişmesinde, hayvan fizyolojisindeki birtakım yaşamsal faaliyetlerde rol oynadığı bilinmekte; Ca eksikliği özellikle genç hayvanlarda kemik yumuşamalarına, yaşlılarda ise kemiklerin deforme olmasına, P yetersizliği kemik gelişiminin durmasına, dişlerin kırılmasına, iştahsızlık, halsizlik ve zayıflık görülmesine neden olmakta; Mg eksikliğinde, hayvanlarda çeşitli hastalıklar oluşabileceği gibi, gerekli tedbirler alınmadığı takdirde ölümler de görülebilmektedir (Ensminger ve ark., 1990; Ergül, 1993; Sabah ve Çelik, 2001; Tekeli ve ark., 2003).

Mineral maddeler, organizmada sentezlenmeleri mümkün olmadıkları için esansiyeldirler, yani yaşamsal faaliyetlerin devamı için gereklidirler (Ergül, 1993; Kutlu ve ark., 2005); bu nedenle hayvanların ihtiyacı duyduğu bu maddelerin önemli bir kısmı yemlerle karşılanır (Gökkuş ve ark., 2013; Eğritaş ve Önal Aşc1, 2015). Bitkiler ise ihtiyacı olan besin maddelerini, alınabilir formda olduğu sürece topraktan alabilmektedirler.

Bir yem bitkisinin yem kalitesi denince onun besleme değeri ve yenen miktarı akla gelir. Yem bitkilerinin besleme değerinin belirlenmesinde ise, bitkilerin kimyasal kompozisyonları (Ham protein, ham selüloz, mineraller, vitaminler gibi) önemli ölçütler içerisinde yer almaktadır. Yapılan araştırmalar, yem bitkilerinin kapsadığı mineral madde miktarlarının; bitki türü ve çeşidine (Yolcu ve ark., 2008; Engin ve Mut, 2018; Özyazıcı ve ark., 2018; Polat ve Bayraklı, 2019), biçme çağına-olgunluk devresine (Spears, 1994; Tekeli ve ark., 2003; Can ve Ayan, 2017), kültürel uygulamalara (Karışık ekim, ekim oranı, sulama, gübreleme gibi) (Amrutkar ve ark., 1985; Yolcu, 2008; Yolcu ve Serin, 2009; Eğritaş ve Önal Aşc1, 2015; Arslan ve ark., 2017; Gülümser ve ark., 2017) ve toprak verimliliğine (Aydın ve ark., 1997) göre değişiklik gösterdiği rapor edilmiştir.

$\mathrm{Bu}$ araştırmada, ikinci ürün olarak yetiştirilen sorgum, sudanotu, sorgum $\mathrm{x}$ sudanotu melezi ve mısır çeşitlerinin bazı makro elementler $(\mathrm{P}, \mathrm{K}, \mathrm{Ca}$ ve $\mathrm{Mg}$ ) yönünden içeriklerinin belirlenmesi amaçlanmıştır.

\section{Materyal ve Yöntem}

Araştırma, Türkiye'nin Güneydoğu Anadolu Bölgesi’nde yer alan Siirt ili ekolojik koşullarında, 2016 ve 2017 yıllarında ikinci ürün yetiştirme sezonunda yürütülmüştür. Araştırmada; 2 adet sorgum (Sorghum bicolor L.) çeşidi (Master BMR ve Rox), 1 adet sudanotu (Sorghum sudanense Staph.) çeşidi (Gözde80), 3 adet sorgum $x$ sudanotu melezi (Sorghum bicolor $x$ Sorghum sudanense Stapf) çeşidi (Forage King, Sugar Graze-II ve Greengo) ve 3 adet mısır (Zea mays L.) çeşidi (OSSK-644, Samada-07 ve DKC6101) bitkisel materyal olarak kullanılmıştır.

Araştırmanın yürütüldüğü vejetasyon dönemine (Temmuz-Kasım) ait iklim verileri incelendiğinde; araştırma yılları sıcaklık ortalamasının (sırasıyla, $23.7^{\circ} \mathrm{C}$ ve $24.5^{\circ} \mathrm{C}$ ) uzun yıllar ortalamasından $(22.9$ ${ }^{\circ} \mathrm{C}$ ) yüksek olduğu; aynı vejetasyon döneminde 2016 yılında toplam $104.3 \mathrm{~mm}, 2017$ y1lında ise 102.6 $\mathrm{mm}$ yağış kaydedildiği, bu değerlerin uzun yıllar toplam yağış ortalamasının $(135.8 \mathrm{~mm})$ altında olduğu görülmüştür (Tablo 1).

Araştırmada, tarla denemesi kurulmadan önce $0-20 \mathrm{~cm}$ derinlikten alınan toprak örneklerinin analiz sonuçları Tablo 2'de verilmiştir. Tablo 2 incelendiğinde, birinci yıl deneme alanı topraklarının killi tekstürlü, kireç içeriğinin orta kireçli, organik madde kapsamının az ve alınabilir P miktarının çok az düzeyde olduğu; ikinci yıla ait araştırma topraklarının ise killi-tınlı tekstürlü, kireç içeriğinin kireçli, organik madde ve alınabilir P kapsamının orta düzeyde olduğu belirlenmiştir. Hafif alkalin karakterde ve tuzsuz olan araştırma topraklarının alınabilir $\mathrm{K}$ yönünden yeterli, alınabilir $\mathrm{Ca}$ ve $\mathrm{Mg}$ yönünden ise iyi düzeyde olduğu saptanmıştır (Tablo 2).

Araştırmada tarla denemeleri, tesadüf blokları deneme desenine göre 3 tekrarlamalı olarak kurulmuştur. Her parselde 6 sıra halinde, $70 \mathrm{~cm}$ sıra arası mesafe (Anonim, 2016a, 2016b) ile ekim yapılmış olup; parsel büyüklüğ̈̈ $4.20 \mathrm{~m}$ x $6.00 \mathrm{~m}=25.2 \mathrm{~m}^{2}$ 'dir. Tablo 2 'deki toprak analizi sonuçlarına göre, her parsele homojen miktarda olacak şekilde; ilk yll için $7 \mathrm{~kg} / \mathrm{da}$ ve $15 \mathrm{~kg} / \mathrm{da}$, ikinci yll için ise $2 \mathrm{~kg} / \mathrm{da}$ ve $14 \mathrm{~kg} / \mathrm{da}$ sirasiyla saf $\mathrm{P}_{2} \mathrm{O}_{5}$ ve saf $\mathrm{N}$ olacak şekilde fosforlu gübre (Triple süper fosfat, \% 43-44 $\mathrm{P}_{2} \mathrm{O}_{5}$ ) ve azotlu gübre (Amonyum sülfat, \% $21 \mathrm{~N}$ ) uygulanmıştır. Fosforlu gübrenin tamamı ve azotlu gübrenin yarısı ekimle birlikte açılan sıralara, azotlu gübrenin kalan yarısı ise bitkiler 40-50 cm'de iken boğaz doldurma sırasında verilmiştir. Ekim işlemi; ilk yıl 05 Ağustos 2016, ikinci yıl 25 Temmuz 2017 tarihinde, sorgum çeşitlerinde dekara 2-2.5 kg, mısır çeşitlerinde ise dekara $3 \mathrm{~kg}$ olacak şekilde ekim normu uygulanarak yapılmıştır (Anonim, 2016a, 2016b). 
Tablo 1. Araştırma yerine ait uzun yıllar (1970-2017) ve araştırma yılları bazı iklim verileri (Anonim, 2017)

\begin{tabular}{|c|c|c|c|c|c|c|c|c|c|c|c|c|c|}
\hline Yillari & 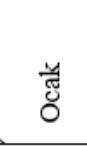 & 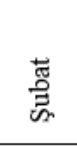 & $\underset{\mathrm{s}}{\mathrm{E}}$ & $\begin{array}{l}\text { 茎 } \\
\text { 学 }\end{array}$ & $\sum_{i}^{\infty}$ & $\begin{array}{l}\text { 콬 } \\
\text { త్山 } \\
\text { 采 }\end{array}$ & 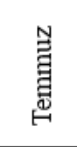 & $\frac{2}{8}$ & 昙 & 署 & $\begin{array}{l}\text { 园 } \\
\text { 㞤 }\end{array}$ & 光 & 売 売 \\
\hline \multicolumn{14}{|c|}{ Ortalama S1caklik $\left({ }^{\circ} \mathrm{C}\right)$} \\
\hline 2016 & 1.7 & 8.1 & 10.1 & 16.6 & 19.9 & 26.5 & 31.4 & 32.3 & 25.0 & 19.5 & 10.4 & 3.3 & 17.1 \\
\hline 2017 & 3.0 & 2.7 & 9.6 & 14.0 & 19.5 & 26.9 & 32.3 & 32.0 & 28.4 & 18.4 & 11.2 & 8.0 & 17.2 \\
\hline $1970-2017$ & 2.8 & 4.4 & 8.7 & 14.1 & 19.5 & 26.2 & 30.6 & 30.1 & 25.2 & 18.1 & 10.3 & 4.7 & 16.2 \\
\hline \multicolumn{14}{|c|}{ Nispi Nem (\%) } \\
\hline 2016 & 76.2 & 68.3 & 62.3 & 47.5 & 48.9 & 32.7 & 24.5 & 20.5 & 29.8 & 36.8 & 49.7 & 73.1 & 47.5 \\
\hline 2017 & 65.9 & 64.9 & 63.9 & 59.5 & 51.7 & 29.5 & 19.0 & 19.0 & 19.1 & 34.6 & 64.4 & 65.2 & 46.4 \\
\hline $1970-2017$ & 70.5 & 65.6 & 60.3 & 57.3 & 49.2 & 34.0 & 26.8 & 26.1 & 31.0 & 47.2 & 62.2 & 70.1 & 50.0 \\
\hline \multicolumn{14}{|c|}{ Toplam Yağış Miktarı (mm) } \\
\hline 2016 & 196.8 & 63.8 & 136.6 & 66.8 & 64.7 & 20.6 & 2.4 & 0.2 & 19.0 & 27.1 & 55.6 & 121.4 & 775.0 \\
\hline 2017 & 46.4 & 29.2 & 119.2 & 132.8 & 74.6 & 0.0 & 0.0 & 0.4 & 0.0 & 5.2 & 97.0 & 48.2 & 552.0 \\
\hline $1970-2017$ & 72.9 & 89.9 & 98.9 & 96.7 & 59.5 & 9.7 & 3.1 & 2.3 & 4.7 & 47.9 & 77.8 & 83.6 & 647.0 \\
\hline
\end{tabular}

Tablo 2. Araştırma yeri topraklarının bazı fiziksel ve kimyasal özellikleri*

\begin{tabular}{|c|c|c|}
\hline \multirow{2}{*}{ Toprak Özelliği } & \multicolumn{2}{|c|}{ Değeri } \\
\hline & 2016 y1lı deneme yeri & 2017 y1lı deneme yeri \\
\hline Kum, \% & 14.00 & 39.84 \\
\hline Kil, \% & 58.00 & 34.16 \\
\hline Silt, \% & 28.00 & 26.00 \\
\hline $\mathrm{pH}$ & 7.95 & 7.53 \\
\hline Elektriksel İletkenlik, dS/m & 0.107 & 0.150 \\
\hline Kireç $\left(\mathrm{CaCO}_{3}\right), \%$ & 10.5 & 4.2 \\
\hline Organik Madde, $\%$ & 1.35 & 2.22 \\
\hline Alınabilir $\mathrm{P}, \mathrm{kg} \mathrm{P}_{2} \mathrm{O}_{5} / \mathrm{da}$ & 2.3 & 7.9 \\
\hline Alınabilir $\mathrm{K}, \mathrm{kg} \mathrm{K}{ }_{2} \mathrm{O} / \mathrm{da}$ & 163 & 117 \\
\hline Alınabilir Ca, ppm & 15142 & 3983 \\
\hline Alınabilir Mg, ppm & 1568 & 370 \\
\hline
\end{tabular}

*: Analizler, Siirt Üniversitesi, Bilim ve Teknoloji Uygulama ve Araştırma Merkezi Laboratuvarı’nda yapılmıştır.

Bitkiler, 2-4 yapraklı olduğu dönemde (yaklaşık 15-20 cm yüksekliğe ulaştıkları zaman) birinci çapa ile birlikte tekleme ve aynı zamanda yabancı ot mücadelesi yapılmıştır. İkinci çapa ve boğaz doldurma, bitkiler 40-50 cm boylandığında, 6-8 yapraklı olduğu dönemde yapılmıştır (Anonim, 2016a, 2016b). İklim ve toprak şartlarına göre, bitkinin gelişme durumu/genel görünümü dikkate alınarak, her parsele eşit olacak şekilde damla sulama sistemi ile sulamalar yapılmıştır.

Hasat sırasında, her parselin başından ve sonundan $0.5 \mathrm{~m}$ 'lik kısmı ile parsel kenarlarından birer sıra kenar tesiri olarak atılmıştır. Hasat işlemi, vejetasyon süresi boyunca; mısır çeşitlerinde koçandaki tanelerin süt olum dönemlerini tamamlayıp hamur olum dönemine geçtiği, sorgum türlerinde ise tanelerin hamur oluma ulaştığı dönemde (İptaş, 1993; Geren, 2000; Geren ve Kavut, 2009; Anonim, 2016a, 2016b) yapılmıştır.

Hasat sonunda her parselden tesadüfi olarak bitkinin tüm aksamını kapsayacak şekilde örnekler alınmış, usulüne uygun olarak kurutulmuş ve öğütülmüştür. Öğütülen örneklerde $\mathrm{P}, \mathrm{K}, \mathrm{Ca}$ ve $\mathrm{Mg}$ analizleri; Ondokuz Mayıs Üniversitesi Ziraat Fakültesi Tarla Bitkileri Bölümü Laboratuvarı'nda, NIRS (Near Infrared Reflektance Spectroscopy-Yakın Kızıl Ötesi Yansıması Spektroskopisi) cihazı ile \#IC-0904FE kalibrasyon seti (Anonymous, 2018) kullanılarak belirlenmiştir (Brogna ve ark., 2009).

Araştırma sonunda elde edilen verilerde, her bir özellik için homojenlik testi yapılmış olup, varyanslar homojen çıkmıştır. Buna göre iki yıllık veriler tesadüf blokları deneme desenine göre varyans analizine 
tabii tutulmuş; F testi sonuçlarına göre gruplar arasındaki farklılıklar Tukey çoklu karşılaştırma testi ile belirlenmiştir (Açıkgöz ve Açıkgöz, 2001).

\section{Bulgular ve Tartışma}

\subsection{Fosfor}

İkinci ürün olarak yetiştirilen sorgum, sudanotu, sorgum x sudanotu melezi ve mısır çeşitlerinde belirlenen P oranları Tablo 3'te sunulmuştur. İki yıllık verilerle yapılan varyans analizi sonucunda, araştırmada ele alınan türler ve çeşitler arasında $P$ oranı bakımından istatistiksel olarak $\mathrm{p}<0.01$ düzeyinde önemli farklılık meydana gelmiştir. İncelenen türlere ait çeşitler içerisinde en yüksek P oranı, istatistiki açıdan birinci grubu oluşturan sorguma ait Master BMR çeşidi (\% 0.30) ile sorgum x sudanotu melezine ait Forage King (\% 0.30) çeşidinde belirlenmiştir. En düşük P oranı ise \% 0.25 ile sudanotuna ait Gözde80 ve mısıra ait Samada-07 çeşidinde saptanmıştır (Tablo 3). Farklı ekolojilerde farklı bitki tür ve çeşitleri/genotipleri ile yapılan birçok araştırma bulgularında da, araştırmamız sonuçlarında olduğu gibi, bitki türleri ve aynı türün genotipleri arasında bile önemli farklılıkların olduğu bildirilmiştir (Vance ve ark., 2003; Hammond ve ark., 2009; Korkmaz ve ark., 2009; Öner ve ark., 2011; Özata ve ark., 2012; Yücel ve ark., 2014; Akgün, 2015; Bozkurt ve Kara, 2018).

Kuru madde içerisindeki P oranının; Öner ve ark. (2011) mısır çeşitlerinde \% 0.21-0.35, Özata ve ark. (2012) mısır genotiplerinde \% 0.11-0.21, Özyazıcı ve ark. (2018) dallı darı çeşitlerine ait silajlarda \% 0.27-0.32 arasında değişim gösterdiğini, Arslan ve ark. (2017) sorgum (S. bicolor L.) silajında \% 0.22 olduğunu bildirmişlerdir. Ayrıca, Özata ve ark. (2012), araştırmamıza konu olan OSSK-644 ve Samada07 mısır çeşitlerinde P oranının sırasıyla \% 0.14 ve \% 0.11 olduğunu rapor etmişlerdir.

Fosfor oranı yönünden yıl x çeşit interaksiyonu incelendiğinde; birinci yıl verilerine göre en yüksek $\mathrm{P}$ oranı Master BMR çeşidinde (\% 0.31), ikinci yıl ise OSSK-644 (\% 0.31) elde edilmiş; bazı çeşitlerin yıllara göre $\mathrm{P}$ içerikleri değişiklik göstermiştir. Bunun sonucu olarak, $\mathrm{P}$ oranı yönünden yıl x çeşit interaksiyonu istatistiki açıdan çok önemli çıkmıştır (Tablo 3). Bu duruma; yıllar itibariyle, topraktaki alınabilir fosforun topraktaki $\mathrm{Ca}$ ve $\mathrm{Mg}$ miktarına göre değişkenlik göstermesinden kaynaklandığı düşünülmektedir.

Yem rasyonlarında hayvanların P ihtiyacının minimum düzeyde karşılanabilmesi için yemlerde \% 0.40 oranında P bulunması gerektiği bildirilmektedir (Muller, 2009). Bu duruma göre, P yönünden sorgum ve mısır çeşitlerinin, ruminantların ihtiyacını karşılamaktan uzak olduğunu söylemek mümkündür.

Buna ek olarak; Jones ve ark. (1991) tarafindan bildirilen misir ( $<\%$ 0.30: noksan, \% 0.30-0.50: yeterli, >\% 0.50: fazla) ve $S$. vulgare (\% $0.25-0.29$ : noksan, $\% 0.30-0.60$ : yeterli, $>\% 0.60$ : fazla) bitkilerine ait $\mathrm{P}$ sınır değerleri ile araştırmamızdaki çeşitlerin $\mathrm{P}$ içerikleri kıyaslandığında; mısır çeşitlerinin tamamının, Master BMR ve Forage King hariç diğer sorgum çeşitlerinin kuru maddesinin içerdiği P oranının kritik düzeyin altında olduğu görülmüştür. Bitkilerin kuru maddesindeki P oranının düşük olmasında; her ne kadar araştırmanın yürütüldüğü toprakların alınabilir P içeriklerine göre (Tablo 2) fosforlu gübre ekim ile birlikte bitkilere verilse de, toprakların Ca ve $\mathrm{Mg}$ içeriklerinin yüksek olması nedeniyle mevcut fosforun toprakta tutulmasının, dolayısıyla bitkiler tarafından fosforun alınımının engellenmesinin etkili olduğu düşünülmektedir.

\subsection{Potasyum}

Yılların ortalamasına göre, incelenen tür ve çeşitlerde en yüksek K oranı \% 2.20 ile sorgum x sudanotu melezine ait Greengo çeşidinde, en düşük değer ise mısıra ait Samada-07 (\% 1.31) çeşidinde tespit edilmiştir. Potasyum yönünden araştırmada incelenen tür ve çeşitler arasındaki bu farklılık, istatistiki olarak çok önemli $(\mathrm{p}<0.01)$ bulunmuştur (Tablo 3). Kuru otların içerdiği K oranlarının çeşitlere göre istatistiksel açıdan anlamlı olarak değişim gösterdiği bazı araştırma sonuçlarında da rapor edilmiştir (Öner ve ark., 2011; Özata ve ark., 2012; Özyazıcı ve ark., 2018). Mısır genotiplerinde K içeriğini Öner ve ark. (2011) \% 0.072-1.920, Özata ve ark. (2012) \% 0.88-1.40 arasında belirlemişlerdir. Ayrıca, OSSK644 ve Samada-07 mısır çeşitlerinde K oranının sırasıyla \% 1.27 ve \% 1.01 (Özata ve ark., 2012) olduğu rapor edilmiş, bu değerlerin araştırmamızda aynı çeşitlerde belirlenen değerlerden düşük olduğu görülmüştür.

Araştırmada K yönünden, yıllar arasındaki farklılık ile yıl x çeşit interaksiyonu da istatistiksel açıdan çok önemli $(\mathrm{p}<0.01)$ bulunmuştur. İnteraksiyonda, çeşitlerin $\mathrm{K}$ içeriklerinin yıllara göre değişkenlik göstermesi önemli rol oynamıştır (Tablo 3). Bu değişkenlikte çeşitlerin K alımının farklı olmasının yanı sıra yıllar itibariyle toprakların alınabilir $\mathrm{K}$ içeriklerinin de farklı olmasının etkili olduğu düşünülmektedir. Çeşitlerin ortalaması olarak en yüksek $\mathrm{K}$ değeri \% 1.76 ile ilk yıl verilerinde saptanmıştır (Tablo 3). 
Tablo 3. İkinci ürün koşullarında yetiştirilen bazı sorgum (Sorghum sp.) ve mısır (Z. mays L.) çeşitlerinin $\mathrm{P}$ ve K içerikleri (\%)

\begin{tabular}{|c|c|c|c|c|c|c|c|}
\hline \multirow{2}{*}{ Türler } & \multirow{2}{*}{ Çeşitler } & \multicolumn{3}{|c|}{$\mathrm{P}$} & \multicolumn{3}{|c|}{$\mathrm{K}$} \\
\hline & & 2016 & 2017 & Ortalama & 2016 & 2017 & Ortalama \\
\hline \multirow{2}{*}{ Sorgum } & Master BMR & $0.31 \mathrm{a}$ & $0.29 \mathrm{abc}$ & $0.30 \mathrm{~A}$ & $1.70 \mathrm{c}-\mathrm{f}$ & $1.52 \mathrm{ef}$ & $1.61 \mathrm{BCD}$ \\
\hline & Rox & $0.27 \mathrm{abc}$ & $0.27 \mathrm{abc}$ & $0.27 \mathrm{ABC}$ & $1.57 \mathrm{ef}$ & $1.51 \mathrm{ef}$ & $1.54 \mathrm{CDE}$ \\
\hline Sudanotu & Gözde-80 & $0.24 \mathrm{c}$ & $0.26 \mathrm{abc}$ & $0.25 \mathrm{C}$ & $1.52 \mathrm{ef}$ & $1.40 \mathrm{fg}$ & 1.46 DEF \\
\hline \multirow{3}{*}{ Sorgum $\mathrm{x}$ sudanotu melezi } & Forage King & $0.30 \mathrm{ab}$ & $0.29 \mathrm{abc}$ & $0.30 \mathrm{~A}$ & $1.90 \mathrm{bcd}$ & $1.69 \mathrm{c}-\mathrm{f}$ & $1.80 \mathrm{~B}$ \\
\hline & Sugar Graze-II & $0.29 \mathrm{abc}$ & $0.27 \mathrm{abc}$ & $0.28 \mathrm{ABC}$ & $1.82 \mathrm{~b}-\mathrm{e}$ & $1.52 \mathrm{ef}$ & $1.67 \mathrm{BC}$ \\
\hline & Greengo & $0.28 \mathrm{abc}$ & $0.26 \mathrm{abc}$ & $0.27 \mathrm{ABC}$ & $2.28 \mathrm{a}$ & $2.11 \mathrm{ab}$ & $2.20 \mathrm{~A}$ \\
\hline \multirow{3}{*}{ Misir } & OSSK-644 & $0.26 \mathrm{abc}$ & $0.31 \mathrm{a}$ & $0.29 \mathrm{AB}$ & $1.61 \mathrm{def}$ & $1.08 \mathrm{gh}$ & $1.34 \mathrm{EF}$ \\
\hline & Samada-07 & $0.25 \mathrm{bc}$ & $0.25 \mathrm{bc}$ & $0.25 \mathrm{C}$ & $1.50 \mathrm{ef}$ & $1.12 \mathrm{gh}$ & $1.31 \mathrm{~F}$ \\
\hline & DKC6101 & $0.24 \mathrm{c}$ & $0.28 \mathrm{abc}$ & $0.26 \mathrm{BC}$ & $1.95 \mathrm{bc}$ & $1.06 \mathrm{~h}$ & $1.51 \mathrm{C}-\mathrm{F}$ \\
\hline Ortalama & & 0.27 & 0.27 & & $1.76 \mathrm{~A}$ & $1.44 \mathrm{~B}$ & \\
\hline Önemlilik düzeyi & & \multicolumn{3}{|c|}{ Çeşit $^{* *}$, Y1l x Çeşit ${ }^{* *}$} & \multicolumn{3}{|c|}{ Çeşit $^{* *}, Y_{1} 1^{* *}, Y_{1} 1 \times$ Çeşit ${ }^{* *}$} \\
\hline Varyasyon katsay1s1 (\%) & & \multicolumn{3}{|c|}{6.83} & \multicolumn{3}{|c|}{6.71} \\
\hline
\end{tabular}

*: Aynı grupta aynı harfle gösterilen ortalamalar arasındaki farklılık istatistiksel açıdan önemli değildir。 ${ }^{* *}$ : p $<0.01$ düzeyinde farklilık

Yem rasyonlarında K için olması gereken kritik değer [\% 1.0, Muller (2009)] dikkate alındığında; araştırmada ele alınan tüm çeşitlerden elde edilen otun hayvanların ihtiyaç duydukları potasyumu karşılladığı, bu anlamda çeşitlerin K içeriklerinin yeterli düzeyde olduğunu söylemek mümkündür

\subsection{Kalsiyum}

İkinci ürün olarak yetiştirilen sorgum, sudanotu, sorgum x sudanotu melezi ve mısır çeşitlerinde belirlenen $\mathrm{Ca}$ oranları Tablo 4'te sunulmuştur. İki yılın ortalama verilerine göre, $\mathrm{Ca}$ oranı bakımından araştırmada ele alınan türlere ait çeşitler arasındaki farklılık istatistiksel olarak $\mathrm{p}<0.01$ düzeyinde önemli bulunmuştur. Bu farklılık OSSK-644 mısır çeşidi ile diğer çeşitler arasında gerçekleşmiş; en yüksek Ca oranı \% 0.81 ile OSSK-644 mısır çeşidinde saptanmıştır (Tablo 4). Bitkilerin Ca içeriklerinin bitki tür ve çeşitlere göre değiştiği bazı araştırma sonuçlarında da vurgulanmıştır (Lema ve ark., 2004; Yolcu, 2008; Özata ve ark., 2012; Yücel ve ark., 2014).

Tablo 4. İkinci ürün koşullarında yetiştirilen bazı sorgum (Sorghum sp.) ve mısır (Z. mays L.) çeşitlerinin $\mathrm{Ca}$ ve $\mathrm{Mg}$ içerikleri (\%)

\begin{tabular}{|c|c|c|c|c|c|c|c|}
\hline \multirow{2}{*}{ Türler } & \multirow{2}{*}{ Çeşitler } & \multicolumn{3}{|c|}{$\mathrm{Ca}$} & \multicolumn{3}{|c|}{$\mathrm{Mg}$} \\
\hline & & 2016 & 2017 & Ortalama & 2016 & 2017 & Ortalama \\
\hline \multirow{2}{*}{ Sorgum } & Master BMR & 0.69 & 0.67 & $0.68 \mathrm{~B}$ & $0.26 \mathrm{~b}$ & $0.19 \mathrm{de}$ & $0.227 \mathrm{~B}-\mathrm{E}$ \\
\hline & Rox & 0.65 & 0.64 & $0.65 \mathrm{~B}$ & $0.25 \mathrm{~b}$ & $0.24 \mathrm{~b}$ & $0.247 \mathrm{AB}$ \\
\hline Sudanotu & Gözde-80 & 0.60 & 0.63 & $0.61 \mathrm{~B}$ & $0.23 \mathrm{bc}$ & $0.20 \mathrm{~cd}$ & $0.215 \mathrm{DE}$ \\
\hline \multirow{3}{*}{ Sorgum $\mathrm{x}$ sudanotu melezi } & Forage King & 0.75 & 0.65 & $0.70 \mathrm{~B}$ & $0.26 \mathrm{~b}$ & $0.17 \mathrm{de}$ & $0.217 \mathrm{DE}$ \\
\hline & Sugar Graze-II & 0.72 & 0.67 & $0.70 \mathrm{~B}$ & $0.25 \mathrm{~b}$ & $0.17 \mathrm{de}$ & $0.210 \mathrm{E}$ \\
\hline & Greengo & 0.67 & 0.63 & $0.65 \mathrm{~B}$ & $0.25 \mathrm{~b}$ & $0.19 \mathrm{de}$ & $0.220 \mathrm{CDE}$ \\
\hline \multirow{3}{*}{ Misir } & OSSK-644 & 0.85 & 0.77 & $0.81 \mathrm{~A}$ & $0.32 \mathrm{a}$ & $0.20 \mathrm{~cd}$ & $0.262 \mathrm{~A}$ \\
\hline & Samada-07 & 0.78 & 0.63 & $0.71 \mathrm{~B}$ & $0.30 \mathrm{a}$ & $0.17 \mathrm{de}$ & $0.237 \mathrm{BCD}$ \\
\hline & DKC6101 & 0.71 & 0.60 & $0.66 \mathrm{~B}$ & $0.32 \mathrm{a}$ & $0.16 \mathrm{e}$ & $0.240 \mathrm{ABC}$ \\
\hline Ortalama & & $0.71 \mathrm{~A}$ & $0.66 \mathrm{~B}$ & & $0.27 \mathrm{~A}$ & $0.19 \mathrm{~B}$ & \\
\hline Önemlilik düzeyi & & \multicolumn{3}{|c|}{$\operatorname{Çeşit~}^{* *}, Y_{1}{ }^{* *}$} & \multicolumn{3}{|c|}{ Çeşit $^{* *}, Y_{1} 1^{* *}, Y 11 \times$ Çeşit $^{* *}$} \\
\hline Varyasyon katsay1s1 (\%) & & \multicolumn{3}{|c|}{7.40} & \multicolumn{3}{|c|}{5.04} \\
\hline
\end{tabular}

*: Aynı grupta aynı harfle gösterilen ortalamalar arasındaki farkllılı istatistiksel açıdan önemli değildir, **: $p<0.01$ düzeyinde farklilık 
Araştırmada, $\mathrm{Ca}$ yönünden yıllar arasındaki farklılık istatistiki olarak çok önemli $(\mathrm{p}<0.01)$ çıkmış; en yüksek $\mathrm{Ca}$ oranı çeşitlerin ortalaması olarak birinci yılda $(\% 0.71)$ elde edilmiştir. Kalsiyum yönünden yıllar arasındaki bu farklılıkta toprakların alınabilir $\mathrm{Ca}$ içeriklerinin farklı olmasının (Tablo 2) etkili olduğu düşünülmektedir.

Mısır genotiplerinde Ca içeriğini Öner ve ark. (2011) \% 0.21-0.52, Özata ve ark. (2012) \% 0.17-0.37 arasında belirlemişlerdir. Ayrıca, OSSK-644 ve Samada-07 mısır çeşitlerinde Ca oranının sırasıyla \% 0.26 ve \% 0.24 (Özata ve ark., 2012) olduğu rapor edilmiş, bu değerlerin araştırmamızda aynı çeşitlerde belirlenen değerlerden düşük olduğu görülmüştür. Kaba yemlerde yapılan birçok çalışmalar gözden geçirildiğinde, örneğin, Bakoğlu ve ark. (1999) Erzurum yöresi çayır ve meralarındaki buğdaygil türlerinin Ca içeriklerinin \% 0.28-1.52 arasında olduğunu; Eğritaş ve Önal Aşcı (2015) tritikale ve yulaf bitkilerinden elde edilen otun sirasıyla \% 0.37-0.39 ve \% 0.35-0.41 arasında değişen oranlarda $\mathrm{Ca}$ içerdiğini bildirmişlerdir. Arslan ve ark. (2017) sorgum (S. bicolor L.) silajında Ca oranının \% 0.69 olduğunu; Özyazıcı ve Yıldız (2017), meradan elde edilen kuru otların \% 0.86-1.23 arasında Ca içerdiğini rapor etmişlerdir.

Yem rasyonlarında, hayvanların Ca ihtiyacının minimum düzeyde karşılanabilmesi için \% 0.90 oranında Ca bulunması gerektiği (Muller, 2009) dikkate alındığında, araştırmada incelenen çeşitlerin Ca içeriği bakımından ruminantların ihtiyacını karşılayamayacağını söylemek mümkündür.

\subsection{Magnezyum}

İki yıllık verilerle yapılan varyans analizi sonucunda, $\mathrm{Mg}$ oranı yönünden araştırmada ele alınan türlere ait çeşitler arasında istatistiksel olarak $\mathrm{p}<0.01$ düzeyinde önemli farklılık meydana gelmiştir. İncelenen tür ve çeşitler içerisinde en yüksek Mg oranı, iki yılın ortalaması olarak \% 0.262 ile OSSK-644 mısır çeşidinde tespit edilmiş; bu çeşit ile sorguma ait Rox (\% 0.247) ve yine mısıra ait DKC6101 (\% 0.240) çeşidi arasındaki farklılık istatistiki açıdan önemsiz olmuştur. En düşük Mg oranı ise \% 0.210 ile sorgum x sudanotu melezine ait Sugar Graze-II çeşidinde saptanmıştır (Tablo 4). Magnezyum yönünden çeşitler arasındaki farklılık Lema ve ark. (2004), Özata ve ark. (2012), Bozkurt ve Kara (2018) ve Özyazıcı ve ark. (2018) tarafından da rapor edilmiştir. Fageria ve ark. (1997), bitkilerin içerdiği Mg miktarının aynı bitkinin değişik genotipleri arasında da farklılık gösterdiğini bildirmiştir.

Magnezyum oranı yönünden yıl x çeşit interaksiyonu incelendiğinde; en yüksek Mg oranı 2016 yılında \% 0.30-0.32 arasında değişen değerlerle mısır çeşitlerinde (OSSK-644, Samada-07, DKC6101), en düşük Mg oranı ise \% 0.16 ile 2017 yılında DKC6101 misır çeşidinde elde edilmiştir. Tablodan da görüldüğü üzere yıllara göre çeşitlerin içerdiği Mg oranı değişkenlik göstermiştir. Bunun sonucu olarak, Mg oranı yönünden yıl x çeşit interaksiyonu istatistiki açıdan çok önemli çıkmıştır (Tablo 4).

Diğer taraftan araştırmada, yıllar arasındaki farklılık da istatistiki açıdan çok önemli $(\mathrm{p}<0.01)$ bulunmuş, en yüksek Mg oranı, çeşitlerin ortalaması olarak 2016 yılı analizlerinde (\% 0.27) belirlenmiştir (Tablo 4). Magnezyum yönünden yıllar arasındaki bu farklılıkta toprakların alınabilir Mg içeriklerinin farklı olmasının (Tablo 2) etkili olduğu düşünülmektedir.

Kuru maddede Mg oranlarının; Erzurum yöresi çayır meralarını teşkil eden buğdaygil türlerinde 1062 2590 ppm (Bakoğlu ve ark., 1999), silajlık hibrit misır çeşitlerinde \% 0.16-0.29 (Öner ve ark., 2011) ve \% 0.17-0.34 (Özata ve ark., 2012), Van yöresi mera kuru otlarında \% 0.20-0.22 (Özyazıc1 ve Yıldız, 2017), dallı darı çeşitlerinde \% 0.13-0.16 (Özyazıcı ve ark., 2018) arasında değişim gösterdiğ bildirilmiştir.

Anonymous (2001), büyükbaş hayvan rasyonları için Mg oranı için sınır değerin \% 0.25 olduğunu bildirmektedir. Yıllar ayrı ayrı değerlendirildiğinde, 2016 yılında incelenen tüm çeşitlerin hayvanların ihtiyacını karşılayabilecek düzeyde $\mathrm{Mg}$ içerdiği; çalışmanın ikinci yıl sonuçlarına göre çeşitlerin $\mathrm{Mg}$ oranının kritik değerin altında olduğu görülmüştür. İki yıllık ortalama verilerine göre ise, OSSK-644 mısır çeşidi hariç diğer çeşitlerin yine kritik değerin altında Mg içerdiği belirlenmiştir. Araştırmamız bulgularında, toprakta alınabilir Mg içeriğinin “iyi” düzeyde bulunmasına rağmen (Tablo 2), bitkilerin kuru maddesindeki Mg oranının yetersiz olmasında; Huang (2001) ve Kacar (2012) tarafindan da ifade edildiği üzere, kuraklık stresinin ve toprak sıcaklığının bitkilerin Mg alımını olumsuz yönde etkilediği düşünülmektedir. Nitekim, Özyazıcı ve ark. (2018) tarafından aynı iklim ve toprak şartlarında dallı darı bitkisi ile yapılan araştırmada da bitkilerin Mg içeriği yönünden benzer sonuçlar elde edilmiştir.

\section{$3.5 \mathrm{Ca} / \mathrm{P}$ ve $\mathrm{K} / \mathrm{Ca}+\mathrm{Mg}$ orant}

Bazı besin maddelerinin arasındaki ilişki, örneğin $\mathrm{Ca} / \mathrm{P}$ ve $\mathrm{K} /(\mathrm{Ca}+\mathrm{Mg})$ oranları hayvanların metabolik faaliyetleri ve sağlığı açısından önem taşımaktadır (Kumar ve Soni, 2014; Eğritaş ve Önal Aşc1, 2015). İki yıllık verilerle yapılan varyans analizi sonucunda, $\mathrm{Ca} / \mathrm{P}$ oranı yönünden araştırmada ele alınan türlere ait çeşitler arasındaki farklılık istatistiksel olarak $\mathrm{p}<0.01$ düzeyinde önemli çıkmıştır. En yüksek $\mathrm{Ca} / \mathrm{P}$ oranı OSSK-644 mısır çeşidinde belirlenmiş olup; OSSK-644 çeşidi ile Rox, Gözde-80, Sugar Graze-II, 
Samada-07 ve DKC6101 çeşitleri arasındaki farklılık istatistiki açıdan önemsiz bulunmuştur. En düşük $\mathrm{Ca} / \mathrm{P}$ oranı 2.26 ile Master BMR sorgum çeşidinde belirlenmiştir (Tablo 5).

Tablo 5. İkinci ürün koşullarında yetiştirilen bazı sorgum (Sorghum sp.) ve mısır (Z. mays L.) çeşitlerinin $\mathrm{Ca} / \mathrm{P}$ ve $\mathrm{K} / \mathrm{Ca}+\mathrm{Mg}$ oranları"

\begin{tabular}{|c|c|c|c|c|c|c|c|}
\hline \multirow{2}{*}{ Türler } & \multirow{2}{*}{ Çeşitler } & \multicolumn{3}{|c|}{$\mathrm{Ca} / \mathrm{P}$} & \multicolumn{3}{|c|}{$\mathrm{K} / \mathrm{Ca}+\mathrm{Mg}$} \\
\hline & & 2016 & 2017 & Ortalama & 2016 & 2017 & Ortalama \\
\hline \multirow{2}{*}{ Sorgum } & Master BMR & $2.19 \mathrm{c}$ & $2.32 \mathrm{c}$ & $2.26 \mathrm{C}$ & 1.79 & 1.76 & $1.78 \mathrm{BC}$ \\
\hline & Rox & $2.40 \mathrm{bc}$ & $2.41 \mathrm{bc}$ & $2.41 \mathrm{ABC}$ & 1.75 & 1.71 & $1.73 \mathrm{BC}$ \\
\hline Sudanotu & Gözde-80 & $2.47 \mathrm{bc}$ & $2.44 \mathrm{bc}$ & $2.45 \mathrm{ABC}$ & 1.84 & 1.71 & $1.77 \mathrm{BC}$ \\
\hline \multirow{3}{*}{ Sorgum x sudanotu melezi } & Forage King & $2.44 \mathrm{bc}$ & $2.30 \mathrm{c}$ & $2.37 \mathrm{BC}$ & 1.88 & 2.06 & $1.97 \mathrm{~B}$ \\
\hline & Sugar Graze-II & $2.49 \mathrm{bc}$ & $2.53 \mathrm{abc}$ & $2.51 \mathrm{ABC}$ & 1.89 & 1.81 & $1.85 \mathrm{BC}$ \\
\hline & Greengo & $2.37 \mathrm{bc}$ & $2.40 \mathrm{bc}$ & $2.39 \mathrm{BC}$ & 2.47 & 2.60 & $2.54 \mathrm{~A}$ \\
\hline \multirow{3}{*}{ Misir } & OSSK-644 & $3.28 \mathrm{a}$ & $2.47 \mathrm{bc}$ & $2.88 \mathrm{~A}$ & 1.39 & 1.10 & $1.25 \mathrm{E}$ \\
\hline & Samada-07 & $3.13 \mathrm{ab}$ & $2.58 \mathrm{abc}$ & $2.85 \mathrm{AB}$ & 1.39 & 1.39 & $1.39 \mathrm{DE}$ \\
\hline & DKC6101 & $2.93 \mathrm{abc}$ & $2.18 \mathrm{c}$ & $2.56 \mathrm{ABC}$ & 1.89 & 1.40 & $1.64 \mathrm{CD}$ \\
\hline Ortalama & & $2.63 \mathrm{~A}$ & $2.40 \mathrm{~B}$ & & 1.81 & 1.73 & \\
\hline Önemlilik düzeyi & & \multicolumn{3}{|c|}{ Çeşit $^{* *}, Y_{1} 1^{* *}, Y_{1} 1 x$ Çeşit $^{* *}$} & \multicolumn{3}{|c|}{ Çeşit $^{* *}$} \\
\hline Varyasyon katsay1s1 (\%) & & \multicolumn{3}{|c|}{10.10} & \multicolumn{3}{|c|}{9.62} \\
\hline
\end{tabular}

*: Aynı grupta aynı harfle gösterilen ortalamalar arasındaki farkllılı istatistiksel açıdan önemli değildir, **: $\mathrm{p}<0.01$ düzeyinde farklılık

Açıkgöz (2001) tarafından belirtildiği üzere, genel olarak $\mathrm{Ca} / \mathrm{P}$ oranının 2:1 olması istenmektedir. Araştırmamız sonuçlarında incelenen yıllar ve çeşitler itibariyle $\mathrm{Ca} / \mathrm{P}$ oranının 2.18-3.28 arasında değişim gösterdiği görülmüştür. Bu oranın 7:1'e kadar hayvanların tolere edebildiği (Buxton ve Fales, 1994) düşünüldüğünde, araştırmamızda elde edilen $\mathrm{Ca} / \mathrm{P}$ oranlarının istenilen düzeye yakın değerler taşıdığını söylemek mümkündür. Bu konuda yapılan çalışmalar gözden geçirildiğinde, örneğin; Eğritaş ve Önal Aşcı (2015) tritikale ve yulaf otunda Ca/P oranının 2:1'den küçük olduğunu, Yolcu (2008) arpa ve buğdayda bu oranının 1.56-1.75 arasında değişim gösterdiğini, Can ve Ayan (2017) domuz ayrığı popülasyonlarında $\mathrm{Ca} / \mathrm{P}$ oranının 1.25-1.33 arasında değiştiğini, Gülümser ve ark. (2017) macar fiğ, yaygın fiğ ve yem bezelyesinin arpa ve tritikale ile karışımlarını inceledikleri çalışmada $\mathrm{Ca} / \mathrm{P}$ oranını 1.94-2.17 arasında değiştiğini rapor etmişlerdir.

$\mathrm{K} / \mathrm{Ca}+\mathrm{Mg}$ oranı incelendiğinde, iki yılın ortalamasına göre en yüksek $\mathrm{K} / \mathrm{Ca}+\mathrm{Mg}$ oran 2.54 ile Greengo sorgum $\mathrm{x}$ sudanotu melezi çeşidinde, en düşük değer ise 1.25 ile OSSK-644 mısır çeșidinde belirlenmiştir. Çeşitler arasındaki bu farklılık istatistiksel olarak $\mathrm{p}<0.01$ düzeyinde önemli çıkmıştır. Araştırmada incelenen türlere ait çeşitlerin $\mathrm{K} / \mathrm{Ca}+\mathrm{Mg}$ oranının yıllar itibariyle 1.10-2.60 arasında değişim göstermiştir (Tablo 5). Yem bitkilerinde $\mathrm{K} /(\mathrm{Ca}+\mathrm{Mg}$ ) oranının ise 2.2 'den düşük olması gerektiği bildirilmekte (Kidambi ve ark., 1989); bu oranının 2.2 veya daha üstünde olması durumunda ot tetanisi riskinin arttığı bazı araştırmacılar tarafindan rapor edilmiş̧ir (Elkins ve ark., 1977; Crawford ve ark., 1998; Şahinoğlu, 2010; Gür, 2014). Literatürdeki bu bilgilerin ışığı altında, araştırmamızda incelenen çeşitlerde belirlenen $\mathrm{K} / \mathrm{Ca}+\mathrm{Mg}$ oranı (Greengo çeşidi hariç) çayır tetanisi için sınır değer olan 2.2'den düşük bulunmuştur (Tablo 5).

Farklı buğdaygil tür ve çeşitleri ile yapılan araştırmalarda, $\mathrm{K} / \mathrm{Ca}+\mathrm{Mg}$ oranının $0.26-3.11$ arasında değişiklik gösterdiği rapor edilmiştir (Yolcu, 2008; Eğritaş ve Önal Aşc1, 2015; Can ve Ayan, 2017).

\section{Sonuc}

İkinci ürün olarak yetiştirilen sorgum ve mısır çeşitlerinin bazı makro bitki besin elementi düzeylerinin belirlenmesi amacıyla yürütülen bu çalışma sonucunda; araştırmada incelenen sorgum ve mısır çeşitlerine ait kaba yemlerin $\mathrm{P}, \mathrm{Ca}$ ve $\mathrm{Mg}$ yönünden yetersiz olduğu ve kaba yemlerin bu makro element içerikleri bakımından ruminantların ihtiyacını karşılamaktan uzak olduğu görülmüştür. Dolaysıyla bitkilerin yetiştirildikleri ortamdan yeterince fosfor, kalsiyum ve magnezyumu alamadıkları söylenebilir. Potasyum bakımından ise araştırmada incelenen sorgum ve mısır çeşitlerinin beslenme problemi yaşamadığı tespit edilmiştir. 
Bitkilerin $\mathrm{P}, \mathrm{Ca}$ ve $\mathrm{Mg}$ yönünden besleme problemlerini yaşaması, yetiştirilen toprakların fiziksel ve kimyasal özellikleri ile ilişkili olduğu düşünülmektedir. Bu nedenle adi geçen bitkiler yönünden toprakbitki besleme ilişkisine yönelik daha detaylı araştırmaların yapılması gerekmektedir. Bununla birlikte, özellikle killi havalanması güç topraklarda bitki köklerinin besin elementi alımında zorluk yaşaması nedeniyle $\mathrm{P}, \mathrm{Ca}$ ve $\mathrm{Mg}$ elementleri yönünden yaprak gübrelemesinin dikkate alınması önerilebilir.

\section{Kaynaklar}

Açıkgöz, E. (2001). Yem Bitkileri. Uludağ Üniversitesi Güçlendirme Vakfı Yayın No: 182, Bursa, $584 \mathrm{~s}$.

Açıkgöz, N., \& Açıkgöz, N. (2001). Tarımsal araştırmaların istatistiki değerlendirilmesinde yapılan bazı hatalar: I. Tek faktörlü denemeler. Anadolu, 11(1), 135-147.

Akgün, M. (2015). Yerel mısır (Zea mays L.) genotiplerinin fosfor kullanım etkinliğinin belirlenmesi. (Yüksek Lisans Tezi), Ordu Üniversitesi Fen Bilimleri Enstitüsü, Ordu, 56s.

Amrutkar, V.L., Deshmukfi, A.P. \& Desale, J.S. (1985). effects of nitrogen and phosphorus fertilization on chemical composition and in vitro dry matter digestbility of gigant baysa. Journal of Maharashtra Agricultural Universities, 10, 93-94.

Anonim. (2016a). Tarımsal Değerleri Ölçme Denemeleri Teknik Talimatı, Sorgum (Sorghum spp.), 2010. T.C. Tarım ve Köyişleri Bakanlığı, Tarımsal Üretim ve Geliştirme Genel Müdürlüğü Tohumluk Tescil ve Sertifikasyon Merkezi Müdürlüğü, Ankara, (http://www.tarim.gov.tr/BUGEM/TTSM/Belgeler/Tescil/ Teknik\%20Talimatlar/S\%C4\%B1 cak\%20\%C4\%B0klim\%20Tah\%C4\%B1llar\%C4\%B1/sorgum.pdf), (Erişim tarihi: 18.04.2016).

Anonim. (2016b). Tarımsal Değerleri Ölçme Denemeleri Teknik Talimatı, Mısır (Zea mays L.), 2010. T.C. Tarım ve Köyişleri Bakanlığı, Tarımsal Üretim ve Geliştirme Genel Müdürlüğü Tohumluk Tescil ve Sertifikasyon Merkezi Müdürlüğü, Ankara, (https://www.tarim.gov.tr/BUGEM /TTSM/Belgeler/Tescil/ Teknik\%20Talimatlar/S\%C4\%B1 cak\%20\%C4\%B0klim\%20Tah\%C4\% B1llar\%C4\%B1/m\%C4\%B1s\%C4\%B1r.pdf), (Erişim tarihi: 18.04.2016).

Anonim. (2017). Meteoroloji Genel Müdürlüğü, Siirt İli İklim Verileri. (https://www.mgm. gov.tr/veridegerlendirme/il-ve-ilceler-istatistik.aspx?k=A\&m=SIIRT), Erişim tarihi: 28.11.2019.

Anonymous. (2001). Nutrient Requirements of Dairy Cattle. Seventh Revised Edition. (http://books.nap.edu/openbook.php?record_id=9825\&page=110), Erişim tarihi: 15.11.2019.

Anonymous. (2018). WinISI 4 Calibration Software: Ground, expandable equation packages (http://www.winisi.com/product_calibrations.htm), Erişim tarihi: 20.01.2018.

Arslan, M., Erdurmuş, C., Öten, M., Aydınoğlu, B., \& Çakmakçı, S. (2017). Sorgum ve bazı bitkilerin ile farklı oranlarda karışımlarından hazırlanan silajların kalite özellikleri. Tekirdă Ziraat Fakültesi Dergisi, 14(02), 34-41.

Aydın, İ., Uzun, F., \& Sürücü, A. (1997). Asit reaksiyonlu toprakta kireç, azot ve fosfor uygulamasının macar fiğinde mineral element içeriğine etkisi. Tr. J. of Agriculture and Forestry, 21, 281-288.

Bakoğlu, A., Koç, A., \& Gökkuş, A. (1999). Erzurum yöresi çayır ve mer'alarındaki yaygın bitki türlerinin ömür uzunluğu, çiçeklenmeye başlama tarihi ve ot kalitesi ile ilgili bazı özellikleri. Tr. J. of Agriculture and Forestry, 23(Ek say1 4), 951-957.

Bozkurt, H., \& Kara, B. (2018). Atdişi mısır ve şeker mısırda hasat zamanlarının körpe koçan kalite sınıflarına ve besin element içeriğine etkisi. Türk Tarım ve Doğa Bilimleri Dergisi, 5(1), 1-6. 
Brogna, N., Pacchioli, M.T., Immovilli, A., Ruozzi, F., Ward, R., \& Formigoni, A. (2009). The use of near-infrared reflectance spectroscopy (NIRS) in the prediction of chemical composition and in vitro neutral detergent fiber (NDF) digestibility of Italian alfalfa hay. Ital. J. Anim. Sci., 8(Suppl. 2), 271-273.

Buxton, D.R., \& Fales, S.L. (1994). Plant Environment and Quality, 155-199. Forage Quality, Evaluation and Utilization (Eds. G.C. Fahey, Collins, D.R. Mertens \& L.E. Moser). Madison, WI, USA, 998p.

Can, M., \& Ayan, İ. (2017). Domuz Ayrı̆̆ı (Dactylis glomerata L.) popülasyonlarında gelişme dönemlerine göre verim ve bazı özelliklerin değişimi. KSÜ Doğa Bilimleri Dergisi, 20(2), 160166.

Crawford, R. J., Maisse, M. D., Sleper, D. A., Mayland, H. F. (1998). Use of an experimental highmagnesium tall fescue to reduce grass tetany in cattle. Journal of Production Agriculture, 11, 491496.

Eğritaş, Ö., \& Önal Aşçı, Ö. (2015). Yaygın fiğ-tahıl karışımlarının bazı mineral madde içeriğinin belirlenmesi. Ordu Üniversitesi Akademik Ziraat Dergisi, 4, 13-18.

Elkins, C. B., Haaland, R. L., \& Honeland, C. S. (1977). Tetany potential of forage species as affected by soil oxygen. Proceedings of the XIII International Grassland Congress, pp. 1505-1507.

Engin, B., \& Mut, H. (2018). Bazı yonca (Medicago sativa L.) çeşitlerinin nispi yem değerleri ile kimi mineral madde içeriklerinin biçim sıralarına göre değişimi. Tekirdă̆ Ziraat Fakültesi Dergisi, 15(02), 119-127.

Ensminger, M. E., Oldfield, J. E., \& Heinemann, W.W. (1990). Feeds \& Nutrition, second ed., The Ensminger Publishing Company, California, U.S.A., pp. 890.

Ergül, M. (1993). Yemler Bilgisi ve Teknolojisi. Ege Üniversitesi Ziraat Fakültesi Yayınları No: 487, Bornova-İzmir.

Fageria, N.K., Baligar, V.C., \& Jones, C.A. (1997). Growth and Mineral Nutrition of Field Crops. $2^{\text {nd }}$ Ed., New York: Marcel Dekker.

Geren, H. (2000). Ana ve ikinci ürün olarak yetiştirilen silajlık mısır (Zea mays L.) çeşitlerinde ekim zamanlarının hasıl verimleri ile silaja ilişkin tarımsal özelliklere etkisi üzerinde araştırmalar. (Doktora Tezi), Ege Üniv. Fen Bilimleri Enst. Tarla Bitkileri Anabilim Dalı, Bornova-İzmir, 251s.

Geren, H., \& Kavut, Y. T. (2009). İkinci ürün koşullarında yetiştirilen bazı sorgum (Sorghum sp.) türlerinin mısır (Zea mays L.) ile verim ve silaj kalitesi yönünden karşılaştırılması üzerine bir araştırma. Ege Üniversitesi Ziraat Fakültesi Dergisi, 46(1), 9-16.

Gökkuş, A., Parlak, A. Ö., Baytekin, H., \& Hakyemez, B. H. (2013). Akdeniz kuşağı çalılı meralarında otsu türlerin mineral içeriklerinin değişimi. Tekirdağ Ziraat Fakültesi Dergisi, 10(1), $1-10$.

Gülümser, E., Mut, H., Doğrusöz, M. Ç., \& Başaran, U. (2017). Baklagil yem bitkisi tahıl karışımların ot kalitesi üzerinde ekim oranlarının etkisi. Selçuk Tarım ve Glda Bilimleri Dergisi, 31(3), 43-51.

Gür, M. (2014). Korunan, otlanan ve sürülüp terk edilen doğal meraların bazı işlevleri ile kimi ekolojik faktörler arasındaki ilişkiler. (Doktora Tezi), Namık Kemal Üniversitesi, Fen Bilimleri Enstitüsü, Tekirdăg, 137s. 
Hammond, J. P., Broadley, M. R., White, P. J., King, G. J., Bowen, H. C., Hayden, R., Meacham, M. C., Mead, A., Overs, T., Spracklen W. P. \& Greenwood, D. C. (2009). Shoot yield drives phosphorus use efficiency in Brassica oleracea and correlates with root architecture traits. Journal of Experimental Botany, 60, 1953-1968.

Huang, B. (2001). Nutrient accumulation and associated root characteristics in response to drought stress in tall fescue cultivars. Hort. Science, 36(1), 148-152.

İptaş, S. (1993). Tokat şartlarında birinci ürün silajlık mısır (Zea mays), sorgum (Sorghum vulgare), sudanotu (Sorghum sudanense) ve sorgum-sudanotu melezinin değişik olgunluk devrelerinde yapılan hasatların verim ve silajlık özellikler ile kaliteye etkileri üzerinde araştırmalar. (Doktora Tezi), Ege Üniv. Fen Bilimleri Enstitüsü Tarla Bitkileri Anabilim Dalı, Bornova-İzmir, 133s.

Jones, J. B. Jr., Wolf, B., \& Milis, H. A. (1991). Plant Analysis Handbook. Micro Macro Publishing, Inc.

Kacar, B. (2012). Temel Bitki Besleme. I. Basım, Nobel Akademik Yayıncılık Eğitim Danışmanlık Tic. Ltd. Şti., Yayın No: 206, Fen Bilimleri No: 18, Ankara.

Kidambi, S. P., Matches, A. G., \& Griggs, T. C. (1989). Variability for Ca, Mg, K, Cu, Zn and $\mathrm{K} /(\mathrm{Ca}+\mathrm{Mg})$ ratio among 3 wheat grassess and sainfoin on the southern high plains. Journal of Range Management, 42, 316-322.

Korkmaz, K., İbrikçi, H., Karnez, E., Büyük, G., Ryan, J., Ülger A.C., \& Oguz, H. (2009). Phosphorus use efficiency of wheat genotypes grown in calcerous soils. Journal of Plant Nutrition, 32, 20942106.

Kumar, K., \& Soni, A. (2014). Elemental ratio and their importance in feed and fodder. International Journal of Pure \& Applied Bioscience, 2(3), 154-160.

Kutlu, H. R., Görgülü, M., \& Baykal Çelik, L. (2005). Genel Hayvan Besleme Ders Notu. (http:/www.muratgorgulu.com.tr/ckfinder/userfiles/files/GENEL\%20HAYVAN\%20BESLEME .pdf), Erişim tarihi: 15.10.2019.

Lema, M., Cebert, E., \& Sapra, V. (2004). Evaluation of small grain cultivars for forage in North Alabama. J Sustain Agr., 23, 133-145.

Muller, L. D. (2009). Dietary Minerals for Dairy Cows on Pasture. (www.das.psu.edu/ researchextension/dairy/.../pdf/mineralsforpasture.pdf.), Erișim tarihi: 25.10.2018.

Öner, F., Aydın, İ., Sezer, İ., Gülümser, A., Özata, E., \& Algan, D. (2011). Bazı silajlık mısır (Zea mays L.) çeşitlerinde verim ve kalite özelliklerinin belirlenmesi. IX. Tarla Bitkileri Kongresi, 1215 Eylül, Bursa.

Özata, E., Öz, A., \& Kapar, H. (2012). Silajlık hibrit mısır çeşit adaylarının verim ve kalite özelliklerinin belirlenmesi. Tarım Bilimleri Araştırma Dergisi, 5(1), 37-41.

Özyazıcı, M. A., Eliş, S., Özyazıcı, G., Açıkbaş, S., \& Turan, N. (2018). Farklı dallı darı (Panicum virgatum L.) çeşitlerinden elde edilen silajların bazı makro besin maddesi kapsamı. 1. Uluslararası Battalgazi Multi Disipliner Çalışmalar Kongresi, Tam Metin Kitabı, Cilt III, 7-9 Aralık, Malatya-Türkiye, s. 2398-2407.

Özyazıcı, M. A., \& Yıldız, A. (2017). Türkiye'nin doğusunda yer alan doğal bir meranın toprak ve bitki örtüsünün beslenme dinamiği. KSÜ Doğa Bil. Derg., 20(Özel Sayı), 109-115. 
Polat, H., \& Bayraklı, F. (2019). Konya bölgesi doğal meraları içerisindeki bazı bitkilerin ham protein ve besin elementi içerikleri. Bahri Dağdaş Bitkisel Araştırma Dergisi, 8(1), 132-147.

Sabah, E. \& Çelik, M.Y. (2001). İşçehisar (Afyon) mermer artıklarının hayvan yemi katkı maddesi olarak kullanılabilirliğinin araştırılması. Türkiye III. Mermer Sempozyumu (Mersem '2001), Bildiriler Kitabı, 3-5 Mayıs, Afyon.

Spears, J.W. (1994). Minerals in forages. In: Forage Quality, Evaluation, and Utilization. (Ed: G.C. Fahey). ASA, CSSA, SSA, Wisconsin, pp, 281-317.

Şahinoğlu, O. (2010). Bafra ilçesi Koşu köyü merasında uygulanan farklı ıslah yöntemlerinin meranın ot verimi, yem kalitesi ve botanik kompozisyonu üzerine etkileri. (Doktora Tezi), Ondokuz Mayıs Üniversitesi, Fen Bilimleri Enstitüsü, Samsun, 136s.

Tekeli, A. S., Avcıŏlu, R., \& Ateş, E. (2003). İran üçgülü (Trifolium resupinatum L.)'nde bazı morfolojik ve kimyasal özelliklerin zamana ve toprak üstü biomasına bağlı olarak değișimi. Tarım Bilimleri Dergisi, 9(3), 352-360.

Vance, P. C., Uhde-Stone, C., \& Allan, D. (2003). Phosphorus acquisition and use: Critical adaptations by plants for securing a nonrenewable resource. New Phytologist, 157, 423-447.

Yolcu, H. (2008). Kaba yem olarak kullanılan arpa ve buğday çeşitlerinde ahır gübresi uygulamasının morfolojik, verim ve kalite özelliklerine etkisi. OMÜ Ziraat Fakültesi Dergisi, 23(3), 137-144.

Yolcu, H., Dasc1, M., \& Turan, M. (2008). Mineral content of some lucerne cultivars for livestock. Asian J. Chem., 20, 3919-3925.

Yolcu, H., \& Serin, Y. (2009). The effects of nitrogen and phosphorus fertilization and seeding patterns on chemical composition of lucerne and smooth brome grass intercropping system. Asian J. Chem., 21, 1460-1468.

Yücel, C., Yücel, D., Akkaya, M. R., \& Anlarsal, A. E. (2014). Bazı ümitvar yaygın fiğ (Vicia sativa L.) genotiplerinde kalite özellikleri. KSÜ Doğa Bilimleri Dergisi, 17(1), 8-14. 